\title{
Possibilities of the fish pass restoration
}

\author{
Lea Čubanová \\ Slovak University of Technology in Bratislava \\ Faculty of Civil Engineering, Department of Hydraulic Engineering \\ e-mail: lea.cubanova@stuba.sk
}

\begin{abstract}
According to the new elaborated methodology of the Ministry of Environment of the Slovak Republic: Identification of the appropriate fish pass types according to water body typology (2015) each barrier on the river must be passable. On the barriers or structures without fish passes new ones should be design and built and on some water structures with existed but nonfunctional fish passes must be realized reconstruction or restoration of such objects. Assessment should be done in terms of the existing migratory fish fauna and hydraulic conditions. Fish fauna requirements resulting from the ichthyological research of the river section with barrier. Hydraulic conditions must than fulfil these requirements inside the fish pass body.
\end{abstract}

Key words: fish pass, fish fauna requirements, hydraulic consideration, design parameters

\section{Introduction}

Fish and many other aquatic organisms use rivers and streams as pathways to move between feeding, nursery and spawning grounds. Anthropogenic structures, such as dams or other barriers on the streams are blocking those pathways and dramatically reduce the habitat available and also isolate fish population between 2 barriers without possibility of the upstream migration.

A fish barrier is a structure, either natural or man-made, that prevents the upstream movement of fishes and aquatic organisms. Barriers to prevent the fish migration can be [1]:

- physical structures (e.g. dams, floodgates, causeways and weirs),

- hydraulic (e.g. areas of high velocity flow or turbulence),

- chemical (e.g. pollution, acid sulphate soil discharge and low dissolved oxygen slugs),

- behavioural obstructions (e.g. dark tunnels or unnatural substrates created by pipes).

Habitats where food and refuge are degraded may also impact upon the migration of native fish species. Fish passage barriers can adversely impact native fish by [1]:

- interrupting spawning or seasonal migrations,

- restricting access to preferred habitat and food resources,

- increasing the chance of predation and disease,

- reducing genetic flow between populations through population fragmentation. 


\section{Methodological Guideline}

Reconstruction of the existed fish passes as well as proposal of new ones should be guided by the new Methodological Guideline of the Ministry of Environment of the Slovak Republic: Determination of suitable types of fish passes according to the typology of water bodies (2015) [2].

\subsection{Useful information for the proper design}

Selection of the fish pass construction - according to the Methodological Guideline pool pass is not recommended [2]. Preferred are slot or brush furnished (bristle) fish passes. Nowadays former technical slot pass is classified as poll ramp with barriers and with wide slots. It is its optimization and modification (enlargement and utilization of natural materials) [2].

Advantages of the poll ramps with barriers and with wide slots: they represent the most universal solution for the all fish species and building problems as well. They create deeper and larger water body (as well as migratory route, rest places too) suitable for bigger individuals in comparison to types of fish passes without barriers. Also every pool creates restful flowing with nearly standing water inside and distinctive velocity shadows what is convenient for weak fishes. Nevertheless, for their filling by water fish passes with barriers need lower discharge than fish passes without barriers [2].

Disadvantages of the poll ramps with barriers and with wide slots: some fish do not trust in such constructions because of many transversal barriers which are bypassed by faster flow through the relatively narrower slots. These slots are in the case of wrong design and realization also predisposed to the clogging during operation [2].

Fish pass location - entrance to the fish pass should be located at the main attractive water flow which is outflowing from the hydro power plant, whereas it should not be too far from the migratory barrier (it should be situated close to the downstream barrier) [2].

Route -fish pass routing could not be conducted in right angles and after $2 \mathrm{~m}$ of the exceeded water level difference (difference in elevation) rest pool (basin) could be designed in the case of bigger fish passes. Basin is creating as one bigger resting pool, e. g. lateral bay with zero velocity, which will be minimal sized as one chamber of the fish pass or at least double extended chamber. Resting pool should have horizontal bottom, increased number of refuge boulders (openings between them should fulfil limits for the transition slot) and over the resting pool should overhanging planted bushes because of fish reassurance and their protection against disturbance and predators (e.g. cormorant).

Doped discharge into the fish pass - by extremely unstable or less watery streams $Q_{\text {fish pass }}=$ $\mathrm{Q}_{355}$; by the rivers with average annual discharge $\mathrm{Q}_{\mathrm{a}}>5 \mathrm{~m}^{3} \cdot \mathrm{s}^{-1}$ must be designed discharge for the fish pass more than $0.5 \mathrm{~m}^{3} \cdot \mathrm{s}^{-1}$ [2].

Other recommendations according to the Methodology [2]:

Fish pass river bed should be similar to the natural stream, but stable against erosion, paved by river stones with diameter $25-30 \mathrm{~cm}$, putted into the dense concrete to achieve macroroughness of the bottom. Gaps between stones in cobble-stone pavement fulfil with concrete only into the half, the rest spill by the $10 \mathrm{~cm}$ layer of the gravel-sand. Also look of the barriers should be similar to the nature, could be brick from the river stones on the concrete base or concrete covered by stones. Presently barriers should be possible recommended from the cast concrete to form imitated stone structure. 
New stone bottom of the fish pass channel should be covered by the natural substrate on the largest area: in mountain and piedmont streams by the rubbly-gravel, in lowland streams gravel-sand-clayey substrate. The whole surface of the bottom is necessary to cover by $10 \mathrm{~cm}$ layer of the gravel-sand (by the fish pass on the creek $5 \mathrm{~cm}$ layer), flowing water will this substrate positioning during the fish pass operation as necessary.

By the weir designing it is important to keep smooth junction between the fish pass and river bed bottoms and also equal water depth at the end of the fish pass and downstream weir (e. g. if in the fish pass depth around $60 \mathrm{~cm}$ occurs it is impossible to join river with $40 \mathrm{~cm}$ depth; as depths, water level differences and velocities in the fish pass would be degraded).

It is appropriate to achieve meandering of the streamlines in the fish pass by the chessboard arranged openings in barriers (on the left bank, then on the right bank). Cross barrier should occupy more than half of the cross section river bed; it means that slot in barrier should be narrower than divided barrier. All these measures would create water energy dissipation and local flow shadows in single pools. Chessboard arranged openings (slots) in barriers are not necessary, if upstream and downstream opening big boulders are placed, or by the classical slot fish pass with concrete deflectors (upstream inflow wing of the barrier on one side of the opening and shifted bank pillar (outflow deflector) on the other side). From the viewpoint of hydraulics and also biological respects by such fish passes it is more efficient to line flow openings by the same bank.

\section{Restored fish pass}

Original solid weir in the east part of Slovakia (Fig. 1) with pool fish pass was rebuilt to the inflatable weir with small hydropower plant on the Torysa River. To fulfil conditions for the migratory fish fauna the existing fish pass was under the reconstruction as well. The new fish pass incorporated the original one with rearranged internal environment and was extended downstream as well as upstream respecting existing structures. Assessment was done in terms of the existing migratory fish fauna and hydraulics, as well as considering the routing, designed resting pool and proposed internal environment.

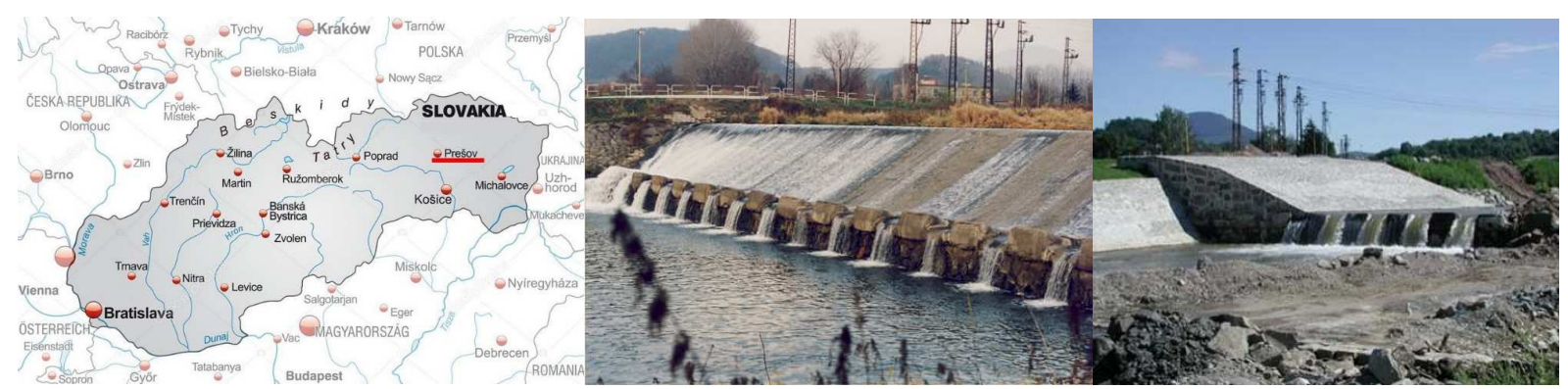

Figure 1: Location of the SHPP, historical solid weir, reconstruction after flood in 2001 [3]

\subsection{Description of the site}

Small hydro power plant Prešov is placed on the Torysa River, in the urban area of the city of Prešov, near by the existed weir and original pool pass. Historic weir was built as solid, concrete. It served as water intake for mill race in city of Prešov. Weir body was hollow, 
without functional sealing construction joints and water infiltrated inside. This was probably reason of the dike right side erosion. River bed in the locality of the weir is $52 \mathrm{~m}$ wide and active width of the river bed bottom was $22 \mathrm{~m}$. In 2001 storm water caused collapsing of the dike right side and water flooded nearby houses and blocks. Therefore $35 \mathrm{~m}$ of the weir was blasted and water returned back to the river bed. After flood, last $5 \mathrm{~m}$ of the weir width was blasted and this weir stop existing after 103 years [3].

During Torysa river bed reconstruction just river bed drop was considered (Fig. 1). From the original weir only lower massive part remained, which created base of the new river bed drop in the river kilometer 62.056 of the Torysa River. Also reparation of the right side of the dike started in 2001 after mentioned flood, but general reconstruction finished in autumn 2004 [3]. Nowadays is in the above mentioned area small hydro power plant with inflatable rubber weir building-up. Also existing pool fish pass had to be rebuilt. The concept of the new fish pass proposal by the new small hydro power plant Prešov consists of utilization and prolongation of the existing pool fish pass [4].

\subsection{Description of the fish pass}

Fish pass is situated on the left bank, by the small hydro power plant. Introduced solution of the designed fish pass results from the assumption of the existed fish pass utilization (interconnection and prolongation) - length $31.5 \mathrm{~m}$. This idea is based on the practical technical-economical and operational-functional consideration, because another route is not feasible. Other placing as original on the left side is impossible because of local road with embedded gas conduit and sewer system, also area of SPP (Slovak Gad Industry) and Slovak Water-Management Company (SVP). On the right side are situated blocks (Sídlisko III), and placing of the fish pass could probably erode right-side of the original threshold solid weir (nowadays is right bank sprinkled), complicated should be also protection against poaching, monitoring and guarding while new small hydro power plant will be situated on the other bank. Original fish pass (and also new designed one) situated on the left side will be protected by the area of the small hydro power plant, with fence, there is minimal rush, traffic, impassable access etc. [4].

\subsubsection{Ichthyological research of the area of interest}

The first and most important data for hydraulic and structural design of the fish pass is to classified affected river section into the fish zones, to choose a suitable type of construction (in this case it is possible only partially) and to consider preliminary hydraulic design. According to the fish zone classification all necessary fish pass channel parameters, doped discharge and others data are developed.

Ichthyological research of the fishing ground Torysa No. 2 downstream weir in the city of Prešov brought useful information for the fish pass optimization. Fish pass should partially make passable this section of the river. Torysa river bed downstream structure is more than 20 $\mathrm{m}$ wide and it is characterized by strong flow of water till to small rapids. Survey on the 100 $\mathrm{m}$ river section detected seven fish species. On this section of the Torysa River the most numerous were European Chub together with Nase Carp and also Barbel. Hunted was just one Trout and from the small species Riffle Minnow which is yearly protected and also seldom occurring Gudgeon [5]. From previous information it could be concluded that Torysa River in 
this section becomes to the barbel zone, annual average discharge is $\mathrm{Q}_{\mathrm{a}}=4.07 \mathrm{~m}^{3} \cdot \mathrm{s}^{-1}$ [6] (according to the fish zone and $\mathrm{Q}_{\mathrm{a}}$ whole fish pass design is proposed).

\subsubsection{Project proposal of the fish pass}

Current linear section of the fish pass (length nearly $31.5 \mathrm{~m}$ ) will be connected with the new construction (right-angled, width $1.6 \mathrm{~m}$ ). Practically immediately after this connection, there is a resting pool following, approximately in the half of the overcoming route [4], dimensions $2 \times 2.4 \mathrm{~m}$, equipped by the natural material [7]. The last fish pass section $(20 \mathrm{~m})$ has reduced longitudinal channel slope, what is helpful for the weaker or exhausted individual to overcome fish pass and swim upstream into the reservoir. Its downstream entrance will be filled according to the actual hydrological situation [4]. Original existed fish pass was prolonged about $5.5 \mathrm{~m}$ downstream towards the small hydro power plant outflow after our consultation and recommendation [7].

Total length of the proposed fish pass according to the project [7] is $78.04 \mathrm{~m}$, water level difference [7]: $250.9 \mathrm{~m}$ a. s. $1 .-245.8 \mathrm{~m}$ a. s. $1 .=5.1 \mathrm{~m}$ and doped discharge: $5001 . \mathrm{s}^{-1}$.

Longitudinal river bed slope of the proposed fish pass according to the project [7]: longitudinal slope is variable according to the local conditions: $7.5 \%$ (river log - 5.5 to 31.47 , by the difference of the river bed altitude $248.6 \mathrm{~m}$ a. s. 1 . and $245.8 \mathrm{~m}$ a. s. 1 .), $8.9 \%$ (river $\log$ 31.47 to 52.7 , by the difference $250.49 \mathrm{~m}$ a. s. 1 . and $248.6 \mathrm{~m}$ a. s. 1 .) and $2 \%$ (river $\log 52.7$ to 72.54 , by the difference $250.9 \mathrm{~m}$ a. s. 1 . and $250.49 \mathrm{~m}$ a. s. 1 .).

Current pool fish pass is changed into the slot fish pass by the modification of the internal environment of the channel. Cross section of the proposed fish pass (Fig. 2) according to the project [7]:

- rectangle cross section, interior width $1.6 \mathrm{~m}$,

- slot width $0.5 \mathrm{~m}$, slots in barriers alternate,

- barrier height above river bed $0.9 \mathrm{~m}$ (including gravel-sand and riverine round stones),

- river bed covered by round stones and sprinkled with gravel-sand,

- barriers lined by boulders,

- length of the pools in the section with the longitudinal slope $2 \%$ is $3 \mathrm{~m}$,

- length of the pools in the other sections is $1.5 \mathrm{~m}$.

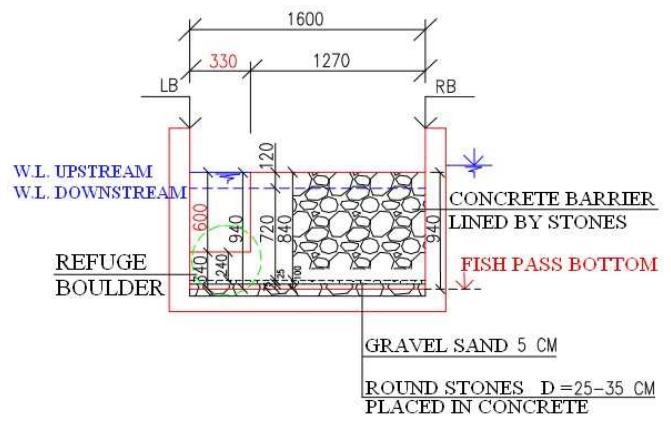

Figure 2. Standard cross section of the designed fish pass [7]

\subsection{Recommendations for the design of the fish pass}

Traditional small-pool fish pass is not suitable for all fish species because of narrowness route in artificially concrete surroundings, frequent clogging of openings, the lack of water or in the 
case of sufficient discharge strong turbulences and foam are occurring (more complicated visual fish orientation). There are also missing restful places, absence of the velocity shadows and fish must often overcome barriers by jumping [2]. Thus, it can be said that the chosen fish pass in project is, given the circumstances and conditions, a good and appropriate choice.

At the entrance to fish pass must be designed additional attractive flow. Rest pool ( 2 x $2.4 \mathrm{~m})$ will be equipped by the natural material and is situated nearly in the middle of the overcoming route [7], it fulfils the requirement that the size of the pool should be at least one chamber of the fish pass. However, other recommendations on the horizontal channel bottom, the increased number of boulders and the bushes planting must be kept. Internal environment assumes natural materials - stones, pebbles, gravel sand, plants. Proposed doped discharge is sufficient for the chosen type of the fish pass and determined fish zone.

Table 1: Parameters of the slot fish pass according to the Methodology [2]

\begin{tabular}{|l|l|l|}
\hline Recommended parameters of the fish pass & barbel zone & barbel-bream zone \\
\hline $\mathrm{Q}_{\mathrm{a}}\left(\mathrm{m}^{3} . \mathrm{s}^{-1}\right)$ & $\geq 5$ & $<5$ \\
\hline $\mathrm{v}_{\max }\left(\mathrm{m} . \mathrm{s}^{-1}\right)$ & $\max .1 .5$ & $\max .1 .0$ \\
\hline$\Delta \mathrm{h}(\mathrm{cm})$ & $\max .12$ & $\max .5$ \\
\hline slot width $(\mathrm{cm})$ & $\min .50$ & $\min .20$ \\
\hline slot height $(\mathrm{cm})$ & $\min .50$ & $\min .30$ \\
\hline water depth downstream/upstream barrier $(\mathrm{cm})$ & $\min .60 / 72$ & $\min .40 / 45$ \\
\hline water level width $(\mathrm{m})$ & $\min .5 \mathrm{~m}$ & $\min .2 \mathrm{~m}$ \\
\hline pool length $(\mathrm{m})$ & $2.5-5$ & $1.5-3$ \\
\hline
\end{tabular}

\subsection{Simple calculations and verification of the preliminary design}

Hydraulic verification of the technical slot fish pass with rectangle openings (and slots in barriers) is done in accordance to the Methodology [2] using known equations:

$$
Q=\frac{2}{3} \mu_{p} \cdot \sigma \cdot b \cdot \sqrt{2 g} \cdot h_{o}^{3 / 2} \Rightarrow b_{s}=\frac{Q}{\frac{2}{3} \mu_{p} \cdot \sigma \cdot \sqrt{2 g} \cdot h_{o}^{3 / 2}}
$$

$\mu_{\mathrm{p}} \quad[--] \quad$ - overflow coefficient (for round stones, pebbles: $\mu_{p}=0,6-0,8[2]$ ),

$\sigma \quad[--] \quad$ - discharge coefficient: $\sigma=1-\left(\frac{h_{\sigma}}{h}\right)^{11}$

$\mathrm{b}_{\mathrm{s}} \quad[\mathrm{m}] \quad-$ the slot width,

g $\quad\left[\mathrm{m} . \mathrm{s}^{-2}\right]-$ acceleration of gravity,

$\mathrm{h}_{\mathrm{o}} \quad[\mathrm{m}] \quad$ - water depth in the slot,

$\mathrm{h}_{\sigma} \quad[\mathrm{m}] \quad$ - depth downstream barrier,

$\mathrm{h}=\mathrm{h}_{\mathrm{o}}[\mathrm{m}] \quad$ - depth upstream barrier. 
Maximum flow velocity, which is occurring in the wide slot, can be calculated using water level difference $\Delta \mathrm{h}$ in the neighbouring pools:

$$
v_{\max }=\sqrt{2 g \Delta h}
$$

$\mathrm{v}_{\max }\left[\mathrm{m} \cdot \mathrm{s}^{-1}\right]-$ maximum flow velocity,

g $\quad\left[\mathrm{m} . \mathrm{s}^{-2}\right]-$ acceleration of gravity,

$\Delta \mathrm{h} \quad[\mathrm{m}] \quad-$ water level difference downstream and upstream slot.

Table 2: Achieved calculated results

\begin{tabular}{|l|l|l|}
\hline & barbel zone & barbel-bream zone \\
\hline $\mathrm{Q}_{\mathrm{a}}\left(\mathrm{m}^{3} \cdot \mathrm{s}^{-1}\right)$ & $\geq 5$ & $<5$ \\
\hline$\Delta \mathrm{h}(\mathrm{m})$ & 0.12 & 0.05 \\
\hline $\mathrm{v}_{\max }\left(\mathrm{m} \cdot \mathrm{s}^{-1}\right)-$ calculated with $\Delta \mathrm{h}$ & 1.5 & 1.0 \\
\hline $\mathrm{b}_{\mathrm{s}}(\mathrm{m})-$ min. width of vertical slot & 0.50 & 0.20 \\
\hline $\mathrm{h}_{\mathrm{s}}(\mathrm{m})-$ depth in vertical slot & 0.60 & 0.65 \\
\hline $\mathrm{h}_{=} \mathrm{h}_{\mathrm{o}}=\mathrm{h}_{\mathrm{s}}+\Delta \mathrm{h}(\mathrm{m})$ & 0.72 & 0.70 \\
\hline $\mathrm{h}_{\sigma}=\mathrm{h}_{\mathrm{u}}(\mathrm{m})$ min. depth in pool downstream barrier & 0.60 & 0.65 \\
\hline$\sigma-$ calculated with $\mathrm{h}_{\sigma}$ and $\mathrm{h}$ & 0.865 & 0.557 \\
\hline $\mathrm{b}_{\mathrm{s}}(\mathrm{m})-$ verification $($ calculated $)$ & $0.53 \approx 0.55$ & $0.74 \approx 0.75$ \\
\hline $\mathrm{Q}_{\text {doped }}\left(\mathrm{m}^{3} \cdot \mathrm{s}^{-1}\right)-$ verification $($ calculated $)$ & 0.52 & 0.51 \\
\hline
\end{tabular}

\section{Conclusion}

From the above described data and facts can be stated that the designed fish pass is trying to accept with its parameters prescribed requirements for the barbel zone, considering local conditions of the project and given situation (reconstruction and completion of the existing fish pass). The advantage of this fish pass could be fact, that just upstream fish pass entrance (outflow from the fish pass) is located transverse sill in the river, which is impassable for counterflowing migrating fish (Fig. 3). This could stimulate fish to look for a more appropriate migratory path and lead up to fish pass outflow. The inflow should be equipped with the coarse screen or floating timber due to prevent entering of the debris and bed load and should be regularly cleaned. Water level at the fish pass outflow (by the outflow from the small hydro power plant) should connected water level in the river downstream weir. It must be underlined that fish pass functioning will depend on keeping of all design parameters, especially on doped discharge, depths, velocities and water level differences on the barriers. Their values should be measured during the test operation of the water structure, whereas it could be adjusting layout of the boulders (adding or removing), set the doped discharge, etc. 

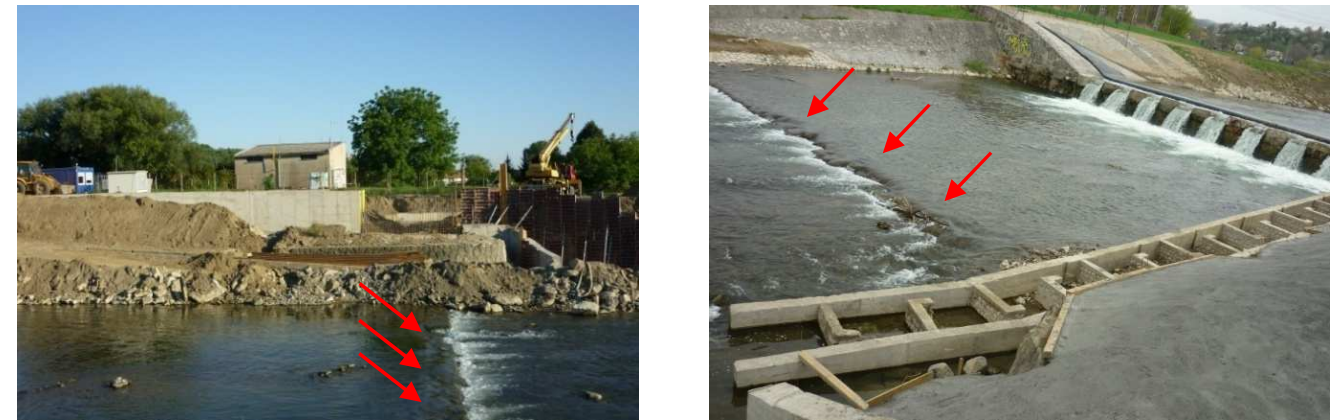

Figure 3. Traverse sill in the Torysa river downstream weir (September 2016, April 2017)

\section{Acknowledgements}

This paper was supported, developed in frame and on the basis of the financial support of the Slovak Research and Development Agency under Contract No. APVV-14-0735: project "New possibilities of use of drainage channels taking the biodiversity in a landscape into account", No. APVV-0680- 10 and also was supported by the VEGA Grant agency under contract No. 1/0800/17: Optimization of the flood protection of municipalities in river basin of mountain streams and under contract No. $1 / 0361 / 17$.

\section{References}

[1] Barriers to fish passage. https://www.dpi.nsw.gov.au/fishing/habitat/threats/barriers $(18 / 05 / 2017)$

[2] Metodické usmernenie MŽP SR: Určenie vhodných typov rybovodov podl'a typológie vodných tokov. VÚVH Bratislava, 2015. (Methodology of the Ministry of Environment of the Slovak Republic: Identification of the appropriate fish pass types according to water body typology).

[3] Fecko, A. Potulky východom - Odstrelili "môj" šlúder. http://fecko.blog.sme.sk/c/158831/Potulky-vychodom-Odstrelili-moj-sluder.html $(18 / 05 / 2017)$

[4] Pšenák, S. Technická správa - rybovod, MVE Prešov. Banská Bystrica, July 2016. (Technical report - fish pass, SHPP Prešov).

[5] Géci, S. Štedrá Torysa, Ichtyologický prieskum rybárskeho revíru Torysa č. 2 pod hat'ou v meste... (Ichthyological research of the Torysa River downstream weir, in the town...) http://polovnictvo.pluska.sk/polovnictvo-rybarstvo/rybar/z-nasich-revirov/2011/stedratorysa.html (18/05/2017).

[6] Hydrologické údaje SHMÚ pre tok Torysa, profil Prešov, hydrologické číslo 4-32-04-078, November 2014. (Hydrological data for the Torysa River, profile Prešov, hydrological no. 4-32-04-078).

[7] Pšenák, S. Rybovod - tvar, v mierke 1:50, Rybovod-pozdľ́ny profil, vzorový rez, v mierke 1:200/100, Situácia, v mierke 1:200, MVE Prešov. (Fish pass - project, scale 1:50, Fish pass - longitudinal section, standard cross section, scale 1:200/100, Layout, scale 1:200, SHPP Prešov). Banská Bystrica, July 2016. 